\title{
EFFECTS OF CORIANDRUM SATIVUM EXTRACT AND SIMVASTATIN IN ISOPRETERENOL INDUCED HEART FAILURE IN RATS
}

Aisha Siddiqi ${ }^{1}$, Adila Parveen ${ }^{2}$, Neha Dhyani ${ }^{1}$, M. Ejaz Hussain ${ }^{2}$ and Mohammad Fahim ${ }^{1}$

${ }^{1}$ Department of Physiology, Hamdard Institute of Medical Sciences and Research, Jamia Hamdard (Hamdard University), Hamdard Nagar, New Delhi-110062, India

${ }^{2}$ Centre for Physiotherapy and Rehabilitation Sciences, Jamia Millia Islamia, Jamia Nagar, New Delhi-110025, India

\author{
EFEKTI EISTRAITA IKORIJANDERA I SIMVASTATINA \\ NA IZOPROTERENOLOM-INDUKOVANU SRČANU \\ INSUFICIJENCIJU KOD PACOVA \\ Aisha Siddiqi ${ }^{1}$, Adila Parveen ${ }^{2}$, Neha Dhyani ${ }^{1}$, M. Ejaz Hussain ${ }^{2}$ и Mohammad Fahim \\ ${ }^{1}$ Katedra za fiziologiju, Hamdard institut medicinskih nauka i istraživanja, Jamia Hamdard (Univerzitet Hamdard), Hamdard Nagar, \\ Nju Delhi-110062, Indija \\ ${ }^{2}$ Centar za fizioterapiju i rehabilitaciju, Jamia Millia Islamia, Jamia Nagar,
} Nju Delhi-110025, Indija

Received / Primljen: 11.10.2017

Accepted / Prihvaćen: 06.12.2017

\begin{abstract}
Heart failure is a syndrome, caused due to structural and functional cardiac abnormalities, characterized by changes in the hemodynamic and neurohumoral mechanisms. It is becoming a major health burden worldwide. More effective therapies are desperately needed. Coriandrum sativum (C. sativum), a traditional spice crop has been known to possess many biological and medicinal properties. The present study was designed to investigate the cardioprotective efficacy of $C$. sativum in rat model of isoproterenol induced heart failure. Heart failure was produced by injecting isoproterenol subcutaneously (85 mg/kg twice at an interval of $24 \mathrm{~h})$. Oral efficacy of seed extract was assessed on hemodynamic profile, antioxidant enzyme activities, lipid peroxidation, lipid profile, atherogenic indices, $m R N A$ and protein expression of endothelin receptors $\left(E T_{A}\right.$ and $\left.E T_{B}\right)$ and histopathology. Treatment of heart failure rats with C. sativum orally $(1 \mathrm{~g} / \mathrm{kg}$ b.wt) improved the altered hemodynamics, restored the cardiac antioxidant enzymes armory, attenuated oxidative stress, improved lipid profile, lowered atherogenic indices, decreased the levels of $E T_{A}$ and $E T_{B}$ receptor $m R N A$ and protein, and restored the cardiac morphology. In conclusion, our results suggest C. sativum to be a cardioprotective agent in heart failure, possibly by the virtue of its ability to alleviate oxidative stress, improve lipid profile and endothelial dysfunction.
\end{abstract}

Keywords: Coriandrum sativum, oxidative stress, heart failure, endothelial dysfunction, endothelin receptors

\section{SAŽETAK}

Insuficijencija srca je sindrom uzrokovan strukturnim $i$ funkcionalnim abnormalnostima srca, a karakteriše se promenama hemodinamskih $i$ neurohumoralnih mehanizama. Insuficijencija srca predstavlja veliki zdravstveni problem širom sveta $i$ zbog toga su neophodne efikasnije terapije. Korijander (C. sativum) je tradicionalno začinsko bilje za koje se zna da poseduje mnoga biološka i terapijska svojstva. Cilj ove studije bio je da ispita kardioprotektivne efekte C. sativuma na modelu srčane insuficijencije izazvane izoproterenom kod pacova. Srčana insuficijencija izazvana je subkutanom injekcijom izoproterenola ( $85 \mathrm{mg} / \mathrm{kg}$ dva puta u intervalu od $24 \mathrm{~h}$ ). Efikasnost per os primenjenog ekstrakta semena korijandera ispitivana je na hemodinamski profil, aktivnost antioksidacionih enzima, peroksidaciju lipida, lipidni profil, aterogeni indeks, $m R N K$, proteinsku ekspresiju endotelnih receptora (ETA $i$ ETB) $i$ histopatologiju. C. sativumom primenjen oralno $(1 \mathrm{~g} /$ $\mathrm{kg}$ TM) doveo je do pobolišanja hemodinamskih parametara, obnovio je srčane antioksidacione enzime, snizio oksidacioni stres, poboljšao lipidni profil, smanjio aterogeni indeks, smanjio nivoe ETA $i$ ETB receptora $m R N A$ i proteina $i$ obnovio srčanu morfologiju. Naši rezultati ukazuju da se C. sativum može koristiti kod srčane insuficijencije kao kardioprotektivni agens, najverovatnije zbog njegove sposobnosti da ublaži oksidacioni stres, poboljša lipidni profil i endotelnu disfunkciju.

Ključne reči: korijander, oksidacioni stres, srčana insuficijencija, endotelna disfunkcija, endotelinski receptori

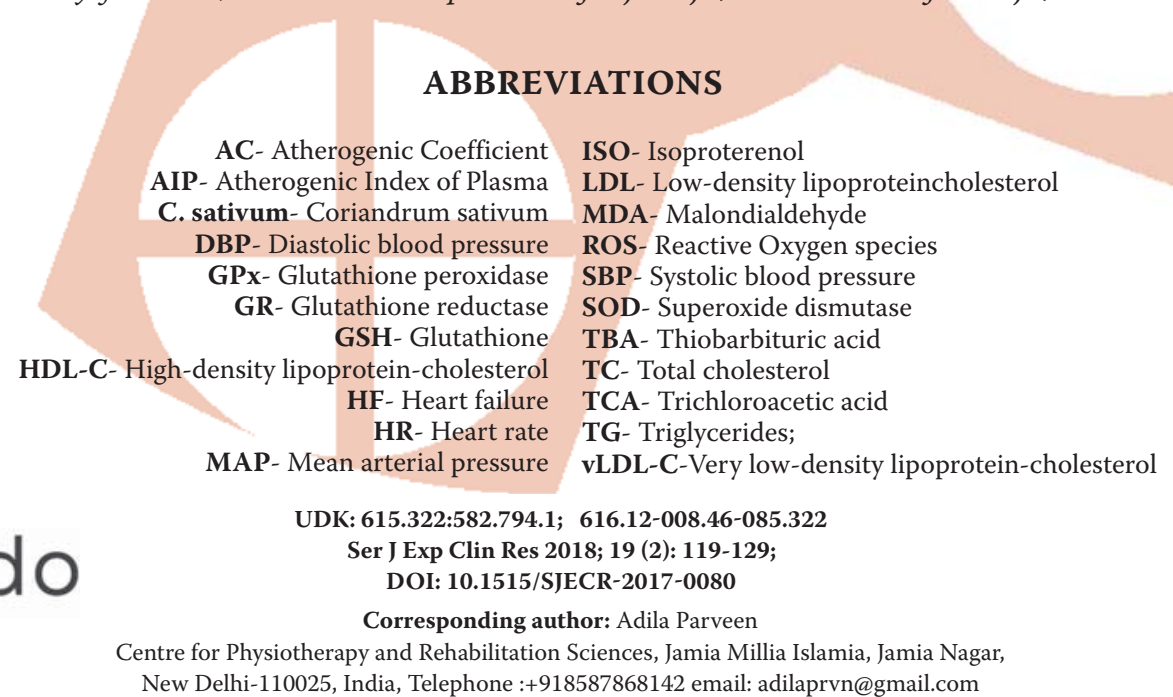




\section{INTRODUCTION}

Heart failure (HF) is a clinical syndrome, caused due to structural and functional cardiac abnormalities, characterized by changes in the hemodynamic and neurohumoral mechanisms that result in inability of the heart to pump blood efficiently. Epidemiological studies suggest high prevalence of cardiovascular diseases out of which heart failure accounts for more than 23 million cases worldwide (1). Major risk factors include ischemic heart disease, hypertension, coronary artery disease, cardiomyopathies, valvular and congenital heart disease, arrhythmias, pericardial disease, and cardiotoxic substances (2). Despite many technological advances in the field of cardiovascular diseases prevention, the incidence and prevalence of HF continue to increase (3).

In the recent years, considerable progress has been made to understand the mechanisms underlying heart failure. Evidence suggests the role of reactive oxygen species (ROS) in the pathogenesis of cardiovascular diseases (4). Increased production of ROS causes peroxidation of cell membrane lipids resulting in cardiac oxidative stress. Lipids are known to regulate cardiac function and altered lipid profile or high cholesterol levels are established predictors of atherogenesis and cardiovascular mortality $(5,6)$. Reduced oxidative stress and cholesterol levels has been associated with cardioprotection mechanisms (7). Vascular endothelin receptors are a class of G-protein coupled receptors that mediate vascular smooth muscle contraction and are known to play an important role in cardiovascular system regulation (8). Several experimental studies have suggested the role of $\mathrm{ET}_{\mathrm{A}}$ and $\mathrm{ET}_{\mathrm{B}}$ receptor systems to be highly dysregulated in chronic heart failure $(8,9)$.

Various treatment modalities for heart failure are available which include aldosterone inhibitors, angiotensin converting enzyme (ACE) inhibitors, angiotensin II receptor blockers (ARBs), beta-blockers, diuretics, calcium channel blockers and digoxin. Statins or 3-hydroxy-3-methylglutaryl-coenzyme A (HMG-CoA) reductase inhibitors is a standard drug used for the treatment of heart failure by the virtue of its lipid lowering properties and hence has shown to reduce the incidence and mortality rate in HF patients (10). Many pleiotropic properties of statins beyond cholesterol reduction include its antioxidant, anti-inflammatory properties, improvement in endothelial dysfunction, release of endothelial progenitor cells, and a number of anti-tumor activities $(11,12)$. Despite many beneficial effects, statins have been reported to cause many adverse effects in the long term (13) which limits the use of statins to a very narrow range. Hence, the need to find an alternate strategy for the prevention and treatment of heart failure is very important.

Investigations are being carried out to study the role of herbal products for the treatment of various diseases as they are considered safe with minimal or no side effects. $C$. sativum, an important spice crop is mainly used in flavouring foods and has also been used as a medicinal plant for the treatment of various diseases (14). C. sativum is known to possess hypolipidemic (15), hypocholesterolemic (16) and antioxidant (17) properties. A study conducted in rats has also shown the cardiopotective action of C. sativum against myocardial necrosis (18).

Till date, no work has been done regarding the cardioprotective aspects of C. sativum in HF model. Therefore, in the light of above inferences, we designed this study to evaluate the therapeutic and prophylactic potential of $C$. sativum on hemodynamic changes, oxidative stress, lipid profile and endothelin receptors, in comparision with simvastatin against isoproterenol induced HF in wistar rats.

\section{MATERIALS AND METHODS}

\section{Animals}

Studies were performed on male Wistar rats (150-200 g, 6-8 weeks old). All experiments were conducted in compliance with the guidelines of the Committee for the Purpose of Control and Supervision of Experiments on Animals (CPCSEA), Government of India, and were approved by the Institutional Animal Ethics Committee. All rats had access to water and rodent chow ad libitum.

\section{Coriandrum sativum seed extract}

Dried coriander seeds (C. sativum) were powdered and mixed with distilled water to make aqueous suspension. It was administered to rats orally at a dose of $1 \mathrm{~g} / \mathrm{kg}$ b.wt. in accordance with Lal et al. (15)

\section{Induction of heart failure (HF) and experimental groups}

HF was induced by subcutaneous injections of isoproterenol $(85 \mathrm{mg} / \mathrm{kg})$ dissolved in normal saline, daily for two consecutive days at an interval of 24h. These animals were kept for 15 days for the development of HF model (19). Animals were randomly divided into 8 groups with 7 rats in each. Group I (Control): Control rats were fed normal pellet diet. Group II (HF): Rats were given ISO ( $85 \mathrm{mg} / \mathrm{kg}$, subcutaneously) once at an interval of $24 \mathrm{~h}$ for two consecutive days and were kept for 15 days. Group III: (Therapeutic simvastatin): Rats were treated as in group II, in addition they received simvastatin $(10 \mathrm{mg} / \mathrm{kg}$; oral gavage) for another 15 days. Group IV (Therapeutic C. sativum): Rats were treated as in group II, in addition they received C. sativum $1 \mathrm{~g} / \mathrm{kg}$; oral gavage) for another 15 days. Group V (Prophylactic simvastatin): Rats were pretreated with simvastatin $(10 \mathrm{mg} /$ $\mathrm{kg}$; oral gavage) for 15 days and at the 15th day subcutaneously injected with ISO $(85 \mathrm{mg} / \mathrm{kg})$ for 2 consecutive days and were continued with simvastatin treatment for another 15 days. Group VI (Prophylactic C. sativum.): Rats were pretreated with C. sativum ( $1 \mathrm{~g} / \mathrm{kg}$; oral gavage) for 15 days and at the 15th day subcutaneously injected with ISO $(85 \mathrm{mg} / \mathrm{kg})$ for two consecutive days and were continued with coriander treatment for another 15 days. Group VII (Simvastatin): Rats were treated with simvastatin $(10 \mathrm{mg} / \mathrm{kg}$; oral gavage) for 15 days. Group VIII (C. sativum): Rats were treated with C. sativum. (1 g/kg; oral gavage) for 15 days. 


\section{Hemodynamic Measurements}

Rats were anaesthetized with intraperitoneal injection of urethane at a dose of $1 \mathrm{gm} / \mathrm{kg}$ b.wt. Disappearance of pedal reflexes indicated adequate anesthesia. Body temperature of the rat was maintained at $37^{\circ} \mathrm{C}$ to $38^{\circ} \mathrm{C}$. Tracheostomy was performed to allow free air breathing without any obstruction. Femoral artery was cannulated by a polyethylene catheter filled with heparin solution $(500 \mathrm{IU} / \mathrm{mL}$, $\mathrm{v} / \mathrm{v})$, for recording arterial blood pressure (ABP). The catheter was attached to a 23-gauge needle connected through a three way stopcock to a pressure transducer (StathamP23D, Oxnard, California). Femoral vein of the other limb was cannulated for injecting drugs. Before recording ABP, the catheter was flushed with heparinized saline solution $(500 \mathrm{IU} / \mathrm{mL}, \mathrm{v} / \mathrm{v})$ to prevent the formation of any blood clot that might interfere with the normal recording of ABP. The pressure recording system was calibrated with a mercury manometer before each experiment. ABP was measured after 20 minutes of stabilization. SBP, DBP, MAP, and HR were recorded on Power Lab data-acquisition system (4SP, AD Instruments, Australia) with a computerized analysis program (Lab Chart 7, AD Instruments).

Post-mitochondrial supernatant preparation and biochemical estimations

Left ventricle was removed quickly, cleaned of extraneous material and immediately perfused with ice-cold saline $(0 \cdot 85 \% \mathrm{NaCl})$ and were then homogenised in chilled phosphate buffer $(0 \cdot 1 \mathrm{M}, \mathrm{pH} 7 \cdot 4)$ containing $\mathrm{KCl}(1 \cdot 17 \%)$ using a Potter-Elvehjen homogeniser. The homogenate was filtered through muslin cloth and centrifuged at $800 \mathrm{~g}$ for 5 min at $4^{\circ} \mathrm{C}$ in a REMI cooling centrifuge to separate the nuclear debris. Aliquot obtained was centrifuged at 12,000 rpm for $20 \mathrm{~min}$ at $4^{\circ} \mathrm{C}$ to obtain the PMS, which was used as a source of enzymes. All biochemical estimations were completed within $24 \mathrm{~h}$ of animal sacrifice.

\section{Estimation of glutathione}

Glutathione (GSH) level was assessed by the method of Jollow et al. (20). A quantity of $1 \mathrm{ml}$ of $10 \%$ PMS mixed with $1 \mathrm{ml}$ of $4 \%$ sulphosalicylic acid, incubated at $4^{\circ} \mathrm{C}$ for $1 \mathrm{~h}$, and then centrifuged at $4^{\circ} \mathrm{C}$ at $1200 \mathrm{~g}$ for $15 \mathrm{~min}$. The reaction mixture of $3 \mathrm{ml}$ was composed of $0.4 \mathrm{ml}$ of supernatant, $2.2 \mathrm{ml}$ phosphate buffer $(0.1 \mathrm{M}, \mathrm{pH} 7.4)$ and 0.4 $\mathrm{ml}$ dithio-bis-2-nitrobenzoic acid $(4 \mathrm{mg} / \mathrm{ml})$. The yellow colour developed was read immediately at $412 \mathrm{~nm}$ on the spectrophotometer (Lambda EZ201; Perkin Elmer). GSH concentration was calculated as $\mu \mathrm{mol}$ GSH conjugates/ mg tissue.

\section{Assay for glutathione peroxidase activity}

Activity of Glutathione peroxidase (GPx) was calculated by the method of Mohandas et al. (21). The total volume of $2 \mathrm{ml}$ was composed of $0.1 \mathrm{ml}$ EDTA ( $1 \mathrm{mM}), 0.1 \mathrm{ml}$ sodium azide $(1 \mathrm{mM}), 1.44 \mathrm{ml}$ phosphate buffer $(0.1 \mathrm{M}, \mathrm{pH}$ $7.4), 0.05 \mathrm{ml}$ glutathione reductase $(1 \mathrm{IU} / \mathrm{ml}$ is equivalent to $1 \mathrm{~mol} \mathrm{GSSG}$ reduced/min per $\mathrm{ml}), 0.05 \mathrm{ml} \mathrm{GSH}(1 \mathrm{mM})$,
$0.1 \mathrm{ml} \mathrm{NADPH}(0.2 \mathrm{mM}), 0.01 \mathrm{ml} \mathrm{H}_{2} \mathrm{O}_{2}(0.25 \mathrm{mM})$ and 0.1 $\mathrm{ml}$ of $10 \%$ PMS. The depletion of NADPH at $340 \mathrm{~nm}$ was recorded at $25^{\circ} \mathrm{C}$. Enzyme activity was calculated as $\mu \mathrm{mol}$ NADPH oxidised/ min per mg protein with a molar extinction coefficient of $6.22 \times 10^{3} \mathrm{M}^{-1} \mathrm{~cm}^{-1}$.

\section{Glutathione reductase activity}

GR activity was determined by the method of Carlberg and Mannervik (22). The reaction mixture consisted of $1.65 \mathrm{ml}$ phosphate buffer $(0.1 \mathrm{M}, \mathrm{pH} 7.6), 0.1 \mathrm{ml}$ EDTA (0.5mM), $0.05 \mathrm{ml}$ GSH $(1 \mathrm{mM}), 0.1 \mathrm{ml} \mathrm{NADPH}(0.1 \mathrm{mM})$ and $0.1 \mathrm{ml}$ of $10 \%$ PMS, in a total volume of $2 \mathrm{ml}$. Enzyme activity was quantified at $25^{\circ} \mathrm{C}$ by measuring the disappearance of NADPH at $340 \mathrm{~nm}$ and was calculated as $\mu \mathrm{mol}$ NADPH oxidized/min per mg protein using a molar extinction coefficient of $6.22 \times 10^{3} \mathrm{M}^{-1} \mathrm{~cm}^{-1}$.

\section{Assay for catalase activity}

Catalase activity was assessed by the method of Claiborne (23). In short, the reaction mixture consisted of 0.05 $\mathrm{ml}$ PMS, $1.0 \mathrm{ml}$ of $\mathrm{H}_{2} \mathrm{O}_{2}(0.019 \mathrm{M}), 1.95 \mathrm{ml}$ phosphate buffer ( $0.1 \mathrm{M}, \mathrm{pH} 7.4)$, in a total volume of $3 \mathrm{ml}$. Changes in absorbance were recorded at $240 \mathrm{~nm}$, and the change in absorbance was calculated as $\mu \mathrm{mol} \mathrm{H}_{2} \mathrm{O}_{2}$ consumed $/ \mathrm{min}$ per mg protein.

\section{Measurement of superoxide dismutase activity}

Superoxide dismutase (SOD) activity was measured by the method of Marklund and Marklund (24). The reaction mixture consisted of $2.875 \mathrm{ml}$ Tris- $\mathrm{HCl}$ buffer $(50 \mathrm{mM}$, pH $8.5)$, pyrogallol (24mM in $10 \mathrm{mM}-\mathrm{HCl})$ and $100 \mathrm{ml} \mathrm{PMS}$, in a total volume of $3 \mathrm{ml}$. Enzyme activity was measured at $420 \mathrm{~nm}$ and was expressed as units/mg protein. One unit of enzyme is defined as the enzyme activity that inhibits the autooxidation of pyrogallol by $50 \%$.

\section{Measurement of lipid peroxidation (LPO)}

Assay for lipid peroxidation (LPO) was done according to the method of Wright et al. (25). The reaction mixture consisted of $0.05 \mathrm{ml}$ serum sample, $0.73 \mathrm{ml}$ phosphate buffer (0.1 M, pH 7.4), $0.2 \mathrm{ml}$ ascorbic acid (100mM) and $0.02 \mathrm{ml}$ ferric chloride $(100 \mathrm{mM})$ in a total volume of $1 \mathrm{ml}$. This mixture was then incubated at $37^{\circ} \mathrm{C}$ in a shaking water bath for $1 \mathrm{~h}$. Reaction was stopped by the addition of $1 \mathrm{ml}$ trichloroacetic acid (10\%). Following the addition of $1 \mathrm{ml}$ thiobarbituric acid (TBA) (0.67\%), all the tubes were placed in a boiling water bath for $20 \mathrm{~min}$. The tubes were shifted to an ice bath, and then centrifuged at $2500 \mathrm{~g}$ for $10 \mathrm{~min}$. Amount of malondialdehyde (MDA) formed in the serum samples was assessed by measuring the optical density of the supernatant at $532 \mathrm{~nm}$ against blank using a molar extinction coefficient of $1.56 \times 10^{5} \mathrm{M}^{-1} \mathrm{~cm}^{-1}$.

\section{Lipid profile}

Serum total cholesterol (TC), triglycerides (TG), lowdensity lipoproteincholesterol (LDL-C), very low-density lipoprotein-cholesterol (VLDL-C) and high-density lipopro- 
tein-cholesterol (HDL-C) were determined by commercially available spectrophotometric assay kits (Monozymes, India).

\section{Atherogenic indices}

Atherogenic indices were calculated as described by Ikewuchi and Ikewuchi (26) using the formulae:

Cardiac Risk Ratio $(C R R)=$ TC $/$ HDL-C

Atherogenic Coefficient $(A C)=(\mathrm{TC}-\mathrm{HDL}-\mathrm{C}) / \mathrm{HDL}-\mathrm{C}$ Atherogenic Index of Plasma $(A I P)=\log (\mathrm{TG} / \mathrm{HDL}-\mathrm{C})$

(The values of TC, TG and HDL-C were converted to $\mathrm{mmol} / \mathrm{l}$ for calculation of atherogenic indices).

RNA isolation and quantitative real-time reverse transcription-polymerase chain reaction

Total tissue RNA was isolated by acid guanidinium thiocyanate-phenol-chloroform extraction method using Trizol reagent (Invitrogen, USA) following the manufacturer's instructions. The tissue was homogenized in trizol ( $0.2 \mathrm{~g}$ tissue per $2 \mathrm{ml}$ trizol) with a Polytron tissue homogenizer. Chloroform extraction, isopropanol precipitation, and $75 \%$ (vol/vol) ethanol washing of precipitated RNA were subsequently performed. The obtained RNA was resolved in diethyl pyrocarbonate (DEPC) treated water. Quantity and quality of RNA extracted was analyzed by NanoDrop (ND-3300, NanoDrop Technologies, USA) and agarose gel electrophoresis. One microgram total RNA was reverse transcribed using RevertAidTM First Strand cDNA Synthesis Kit (Fermentas Life Sciences, USA) as per the manufacturer's recommendations.

Real-time quantitative reverse transcriptase polymerase chain reaction (qRT-PCR) was performed using the Light cycler SYBR Green RT-PCR kit (Roche, U.S.A) with the help of specific primers for endothelin receptor $\mathrm{A}\left(\mathrm{ET}_{\mathrm{A}}\right)$ and endothelin receptor $\mathrm{B}\left(\mathrm{ET}_{\mathrm{B}}\right)$, and normalized to Glyceraldehydes 3-phosphate dehydrogenate (GAPDH) following the standard protocol. Analysis was performed using $\Delta \Delta C_{t}$ method as described earlier (27). The sequence of the primers used is shown in Table 1.

\section{Western blotting}

Total protein was extracted from the heart left ventricle. Protein concentration was determined by Bradford as-

Table 1: Primer sequences of $\mathrm{ET}_{\mathrm{A}}$ receptor, $\mathrm{ET}_{\mathrm{B}}$ receptor and $\mathrm{GAPDH}$ genes for Real Time PCR.

\begin{tabular}{ll}
\hline Gene & Primer Sequence \\
\hline $\mathrm{ET}_{\mathrm{A}}$ receptor (sense) & 5'-ATCGCTGACAATGCTGAGAG-3' \\
$\mathrm{ET}_{\mathrm{A}}$ receptor (antisense) & 5'-CCACGATGAAAATGGTACAG-3' \\
$\mathrm{ET}_{\mathrm{B}}$ receptor (sense) & 5'-GAAAAGAGGATTCCCACCTG-3' \\
$\mathrm{ET}_{\mathrm{B}}$ receptor (antisense) & 5'-ACGAACACGAGGCATGATAC-3' \\
$\mathrm{GAPDH}^{\prime}$ (sense) & 5'-GCCATCAACGACCCCTTCATTG-3' \\
GAPDH (antisense) & 5'-TGCCAGTGAGCTTCCCGTTC-3' \\
\hline
\end{tabular}

say. Denaturation of proteins was performed in 2X Laemmli sample buffer by heating to $95^{\circ} \mathrm{C}$ for $5 \mathrm{~min}$, followed by a quick spin. Total protein $(40 \mu \mathrm{g})$ in each sample was separated by $10 \%$ SDS polyacrylamide gel electrophoresis and transferred to methanol-activated PVDF membrane in Tris-Glycine buffer containing 20\% of methanol. Membranes were blocked by TBST with BSA and incubated with rat polyclonal antiserum raised against rat $\mathrm{ET}_{\mathrm{A}} \mathrm{R}$ (1: 200) and rat $E_{B} R$ (1: 100), followed by incubation with horseradish peroxidase conjugated secondary antibody. $\beta$-actin was used as an internal control. Immunoreactive bands were visualized using an enhanced chemiluminescence (ECL) detection system. Densitometric analysis was performed using image-analysis software to determine the protein level. The band intensities of target proteins were expressed relative to $\beta$-actin and normalized to the percentage of control.

\section{Statistical Analysis}

The results were presented as mean \pm standard error of the mean (SEM). All the data was analyzed by analysis of variance (ANOVA) followed by Tukey multiple comparison tests, for the analysis between the groups. The minimum criterion for statistical significance was set at $\mathrm{P}<0.05$ for all comparisons.

\section{Histopathological Examination}

The heart (left ventricle) was fixed in 10\% formalin solution for histopathological analysis. The sections were examined under light microscope, and photomicrographs were taken. Tissues were embedded in paraffin, sectioned at $4 \mu \mathrm{m}$, and stained with hematoxylin and eosin (H\&E). The sections were examined under light microscope, and photomicrographs were taken.

\section{RESULTS}

Arterial blood pressure and Heart rate

HF rats showed a significant $(\mathrm{p}<0.05)$ decrease in SBP, DBP, HR and MAP as compared to the control group. However, both therapeutic and prophylactic treatment with $C$. sativum and simvastatin significantly $(\mathrm{p}<0.05)$ increased SBP, DBP, HR and MAP compared to the HF group. No significant changes were observed in C. sativum and simvastatin only treated groups. The results are as shown in Figure 1.

\section{Enzymatic and non-enzymatic antioxidant levels}

Table 2 demonstrates the activities of different antioxidant enzymes in response to C. sativum and simvastatin treatment in ISO induced rats. ISO administration significantly reduced cardiac GSH $(\mathrm{p}<0.05)$ levels in HF rats as compared to the control rats. Activities of GR ( $<<0.05)$, GPx $(\mathrm{p}<0.05)$, SOD $(\mathrm{p}<0.05)$ and catalase $(\mathrm{p}<0.05)$ were also found to be decreased in ISO induced rats when compared with the control group. Therapeutic and prophylactic treat- 
A

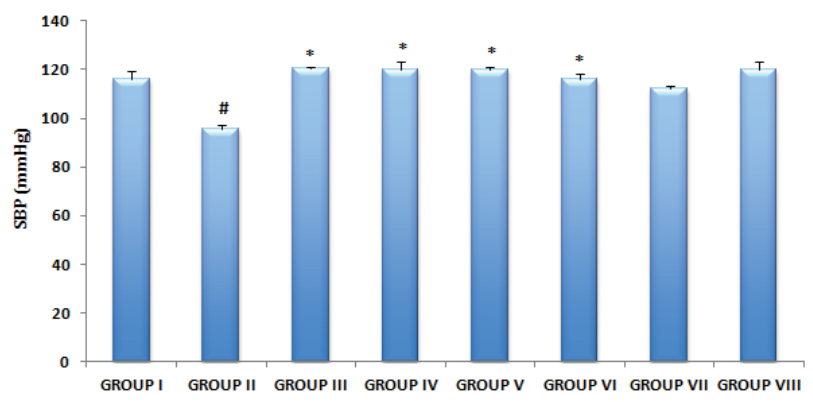

C

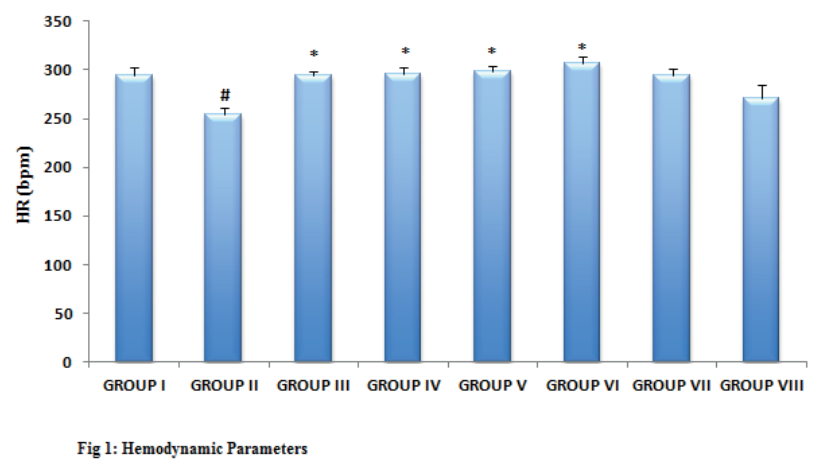

B

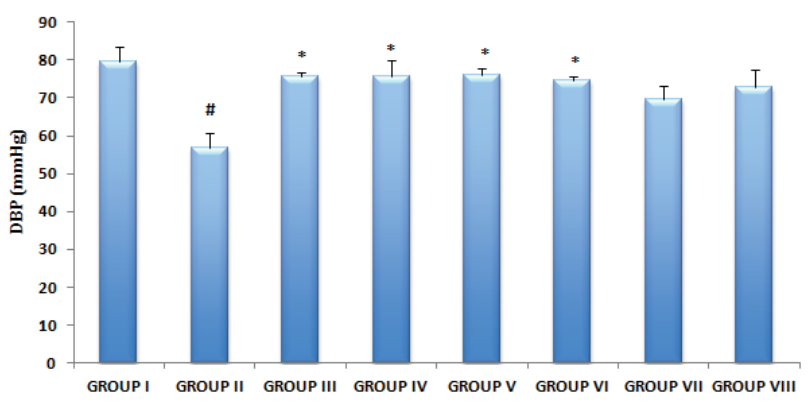

D

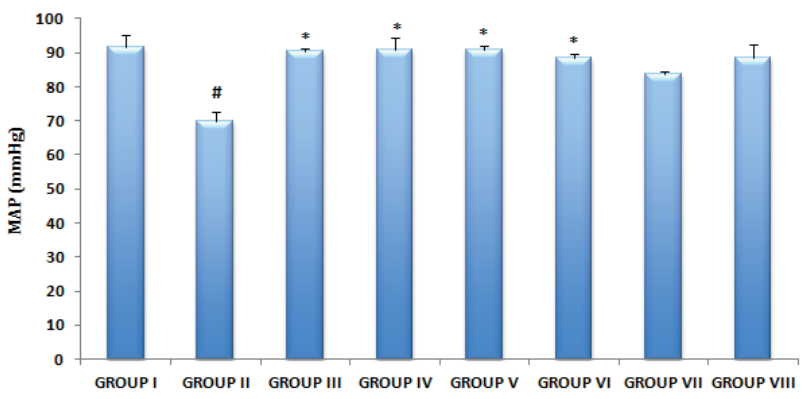

Figure 1: Hemodynamic parameters: (A) Systolic blood pressure (SBP), (B) Diastolic blood pressure (DBP), (C) Heart rate (HR), (D) Mean arterial pressure in Group I (Control); Group II (HF); Group III (Therapeutic simvastatin); Group IV (Therapeutic C. sativum); Group V (Prophylactic simvastatin); Group VI (Prophylactic C. sativum); Group VII (Simvastatin per se); Group VIII (C. sativum per se). Results represent mean \pm SEM of seven animals per group. Results obtained are significantly different from control group $(\# \mathrm{p}<0.05)$. Results obtained are significantly different from HF group $\left({ }^{*} \mathrm{p}<0.05\right)$.

ment with C. sativum and simvastatin however increased the level of GSH $(\mathrm{p}<0.05)$ and activities of GR $(\mathrm{p}<0.05)$, GPx $(\mathrm{p}<0.05)$, SOD $(\mathrm{p}<0.05)$ and catalase $(\mathrm{p}<0.05)$, compared to the HF group. However, no significant difference was found in the C. sativum and simvastatin only treated group, when compared to the control group.

\section{Lipid peroxidation}

In comparision with the control group, levels of MDA increased significantly $(\mathrm{p}<0.05)$ in HF rats. Administration of $C$. sativum and simvastatin both therapeutically and prophylactically showed significant $(\mathrm{p}<0.05)$ reduction in MDA levels when compared with the HF group. C. sati-

Table 2: Effect of simvastatin and Coriandrum sativum treatment on cardiac glutathione (GSH), glutathione peroxidase (GPx), glutathione reductase (GR), superoxide dismutase (SOD) and catalase levels in isoproterenol induced rats.

\begin{tabular}{|c|c|c|c|c|c|}
\hline $\begin{array}{c}\text { Treatment } \\
\text { groups }\end{array}$ & $\begin{array}{c}\text { GSH }(\mu \mathrm{mol} \mathrm{GSH} / \mathrm{g} \\
\text { tissue })\end{array}$ & $\begin{array}{c}\text { GPx }(\mu \mathrm{mol} \text { NADPH } \\
\text { oxidized } / \mathrm{min} / \mathrm{mg} \\
\text { protein })\end{array}$ & $\begin{array}{c}\text { GR }(\mu \mathrm{mol} \text { NADPH } \\
\text { oxidised } / \mathrm{min} / \mathrm{mg} \\
\text { protein })\end{array}$ & $\begin{array}{c}\text { Catalase }\left(\mu \mathrm{mol} \mathrm{H}_{2} \mathrm{O}_{2}\right. \\
\text { consumed } / \mathrm{min} / \mathrm{mg} \\
\text { protein })\end{array}$ & $\begin{array}{c}\text { SOD (units/mg } \\
\text { protein) }\end{array}$ \\
\hline Group I & $4.24 \pm 0.32$ & $7.20 \pm 0.72$ & $9.18 \pm 0.58$ & $88.40 \pm 2.40$ & $3.90 \pm 0.38$ \\
\hline Group II & $1.77 \pm 0.14^{\#}$ & $3.52 \pm 0.24^{\#}$ & $4.50 \pm 0.42^{\#}$ & $42.23 \pm 1.98^{\#}$ & $1.52 \pm 0.22^{\#}$ \\
\hline Group III & $3.25 \pm 0.20^{\circ}$ & $5.19 \pm 0.33^{*}$ & $6.54 \pm 0.24$ & $67.18 \pm 3.20^{\prime \prime}$ & $2.69 \pm 0.20$ \\
\hline Group IV & $3.28 \pm 0.25$ & $5.28 \pm 0.27$ & $6.62 \pm 0.57^{\prime \prime}$ & $68.12 \pm 2.33^{\circ}$ & $2.72 \pm 0.24$ \\
\hline Group V & $3.46 \pm 0.19^{\prime}$ & $6.29 \pm 0.32$ & $8.53 \pm 0.54$ & $71.97 \pm 2.44$ & $3.52 \pm 0.18^{*}$ \\
\hline Group VI & $3.48 \pm 0.28^{\prime \prime}$ & $6.37 \pm 0.30$ & $8.62 \pm 0.32^{*}$ & $72.23 \pm 2.09^{*}$ & $3.57 \pm 0.15$ \\
\hline Group VII & $4.22 \pm 0.31$ & $7.23 \pm 0.42$ & $9.20 \pm 0.44$ & $88.57 \pm 1.11$ & $3.92 \pm 0.24$ \\
\hline Group VIII & $4.25 \pm 0.29$ & $7.28 \pm 0.50$ & $9.23 \pm 0.51$ & $88.73 \pm 2.78$ & $3.94 \pm 0.21$ \\
\hline
\end{tabular}

Results represent mean \pm SEM of seven animals per group. Group I (Control); Group II (HF); Group III (Therapeutic simvastatin); Group IV (Therapeutic C. sativum); Group V (Prophylactic simvastatin); Group VI (Prophylactic C. sativum.); Group VII (Simvastatin per se); Group VIII (C. sativum per se). Results obtained are significantly different from control group (\#p<0.05). Results obtained are significantly different from HF group (*p $<0.05)$. 
Table 3: Effect of simvastatin and coriandrum sativum L. treatment on lipid profile of isoproterenol induced rats.

\begin{tabular}{|c|c|c|c|c|c|}
\hline Treatment groups & $\begin{array}{c}\text { Cholesterol } \\
\text { (mg/dl) }\end{array}$ & $\begin{array}{c}\text { Triglyceride } \\
\text { (mg/dl) }\end{array}$ & $\begin{array}{c}\text { HDL } \\
(\mathrm{mg} / \mathrm{dl})\end{array}$ & $\begin{array}{c}\text { LDL } \\
(\mathrm{mg} / \mathrm{dl})\end{array}$ & $\begin{array}{l}\text { vLDL } \\
(\mathrm{mg} / \mathrm{dl})\end{array}$ \\
\hline Group I & $118.45 \pm 1.48$ & $93.18 \pm 3.10$ & $47.18 \pm 0.82$ & $42.16 \pm 0.73$ & $21.30 \pm 0.84$ \\
\hline Group II & $164.1 \pm 2.43^{\#}$ & $163.33 \pm 3.73^{\#}$ & $22.5 \pm 0.34^{\#}$ & $81.25 \pm 3.42^{\#}$ & $29.56 \pm 0.89^{\#}$ \\
\hline Group III & $148.73 \pm 4.05^{\circ}$ & $146.63 \pm 2.80^{*}$ & $30.33 \pm 0.98^{*}$ & $71.43 \pm 2.13^{*}$ & $25.43 \pm 0.91^{*}$ \\
\hline Group IV & $150.66 \pm 1.87^{\circ}$ & $143.85 \pm 3.71^{*}$ & $28.5 \pm 1.78^{*}$ & $72.46 \pm 2.05^{*}$ & $25.85 \pm 0.46^{*}$ \\
\hline Group V & $132.88 \pm 1.86^{\circ}$ & $111.4 \pm 2.0^{*}$ & $43.1 \pm 0.84$ & $50.06 \pm 1.2^{*}$ & $23.1 \pm 0.45^{*}$ \\
\hline Group VI & $133.33 \pm 2.60^{\circ}$ & $109.03 \pm 2.63^{*}$ & $42.33 \pm 0.55^{*}$ & $51.36 \pm 0.95^{\circ}$ & $23.28 \pm 0.32$ \\
\hline Group VII & $116.91 \pm 1.46$ & $90.7 \pm 2.79$ & $48.3 \pm 0.67$ & $40.36 \pm 0.4$ & $20.33 \pm 0.38$ \\
\hline Group VIII & $117.56 \pm 0.60$ & $91.61 \pm 3.28$ & $47.96 \pm 0.71$ & $41.93 \pm 0.62$ & $21.0 \pm 0.64$ \\
\hline
\end{tabular}

Results represent mean \pm SEM of seven animals per group. Group I (Control); Group II (HF); Group III (Therapeutic simvastatin); Group IV (Therapeutic C. sativum.); Group V (Prophylactic simvastatin); Group VI (Prophylactic C. sativum); Group VII (Simvastatin per se); Group VIII (C. sativum per se). Results obtained are significantly different from control group ( $\# \mathrm{p}<0.05)$. Results obtained are significantly different from HF group (*p $<0.05)$.

vum and simvastatin alone treated groups did not have any significant effect on the serum MDA levels (Figure 2).

\section{Lipid profile}

HF rats showed a significant $(\mathrm{p}<0.05)$ elevation in TC, TG, LDL-C, vLDL-C levels and a significant $(\mathrm{p}<0.05)$ reduction in the level of HDL-C respectively, compared to control rats. Therapeutic and prophylactic treatment with C. sativum and simvastatin significantly $(\mathrm{p}<0.05)$ decreased the levels of TC, TG, LDL-C, vLDL-C and increased $(p<0.05)$ HDL-C levels when compared to HF rats. Treatment with C. sativum and simvastatin alone did not show any significant effect on the lipid profile (Table 3).

\section{Atherogenic indices}

Atherogenic indices were assessed by calculating Cardiac risk ratio (CRR), Atherogenic coefficient (AC) and Atherogenic index of plasma (AIP). A significant $(p<0.05)$ increase in CRR, AC and AIP was observed in HF rats. However, therapeutic and prophylactic treatment with C. sativum and simvastatin showed a significant $(\mathrm{p}<0.05)$ reduction in CRR, $\mathrm{AC}$ and AIP. C. sativum and simvastatin per se treatment showed no significant changes in atherogenic indices when compared with the control group (Table 4).

\section{Expression of $E T_{A}$ and $E T_{B}$ receptor $m R N A$ levels}

Quantitative real-time PCR was used to measure the mRNA levels of $\mathrm{ET}_{\mathrm{A}}$ and $\mathrm{ET}_{\mathrm{B}}$ receptors. Relative mRNA levels of $\mathrm{ET}_{\mathrm{A}}$ receptors in the left ventricle of $\mathrm{HF}$ rats were found to be increased significantly $(\mathrm{p}<0.05)$ as compared with the control group. Both therapeutic and prophylactic treatment with $C$. sativum and simvastatin showed a significant $(\mathrm{p}<0.05)$ decrease in the levels of $\mathrm{ET}_{\mathrm{A}}$ receptor mRNA, when compared to the HF group (Figure 3A). Further, mRNA levels of $\mathrm{ET}_{\mathrm{B}}$ receptor were also found to be significantly $(\mathrm{p}<0.05)$ upregulated in HF group, compared to the normal control group. However, in comparision with the HF group therapeutic and prophylactic treatment with $C$. sativum and simvastatin significantly $(\mathrm{p}<0.05)$ downregulated the expression of $\mathrm{ET}_{\mathrm{B}}$ receptor mRNA (Figure 3B). No significant change was observed

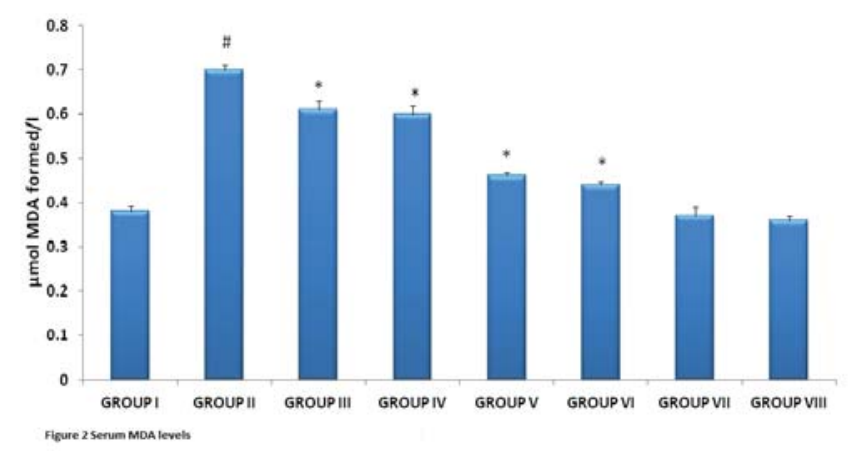

Figure 2: Serum Malodialdehyde (MDA) levels. Results represent mean \pm SEM of seven animals per group. Group I (Control); Group II (HF); Group III (Therapeutic simvastatin); Group IV (Therapeutic C. sativum); Group V (Prophylactic simvastatin); Group VI (Prophylactic C. sativum); Group VII (Simvastatin per se); Group VIII (C. sativum per se). Results obtained are significantly different from control group $(\# \mathrm{p}<0.05)$. Results obtained are significantly different from HF group ("p $<0.05)$.

Table 4: Effect of simvastatin and C. sativum treatment on Atherogenic Indices of isoproterenol induced rats.

\begin{tabular}{cccc}
\hline $\begin{array}{c}\text { Treatment } \\
\text { groups }\end{array}$ & $\begin{array}{c}\text { Cardiac Risk } \\
\text { Ratio (CCR) }\end{array}$ & $\begin{array}{c}\text { Atherogenic } \\
\text { Coefficient } \\
\text { (AC) }\end{array}$ & $\begin{array}{c}\text { Atherogenic } \\
\text { Index of } \\
\text { Plasma (AIP) }\end{array}$ \\
\hline Group I & $2.51 \pm 0.03$ & $1.51 \pm 0.03$ & $-0.06 \pm 0.016$ \\
Group II & $7.30 \pm 0.17^{\sharp}$ & $6.30 \pm 0.17^{\sharp}$ & $0.50 \pm 0.008^{\sharp}$ \\
Group III & $4.92 \pm 0.15^{\star}$ & $3.92 \pm 0.15^{\circ}$ & $0.32 \pm 0.017^{\circ}$ \\
Group IV & $5.41 \pm 0.42^{*}$ & $4.41 \pm 0.42^{\circ}$ & $0.34 \pm 0.023^{\circ}$ \\
Group V & $3.08 \pm 0.07^{*}$ & $2.08 \pm 0.07^{\circ}$ & $0.053 \pm 0.013^{*}$ \\
Group VI & $3.14 \pm 0.04^{*}$ & $2.14 \pm 0.04^{\circ}$ & $0.052 \pm 0.004^{\circ}$ \\
Group VII & $2.37 \pm 0.04$ & $1.37 \pm 0.04$ & $-0.09 \pm 0.014$ \\
Group VIII & $2.45 \pm 0.04$ & $1.45 \pm 0.04$ & $-0.07 \pm 0.015$ \\
\hline
\end{tabular}

Results represent mean \pm SEM of seven animals per group. Group I (Control); Group II (HF); Group III (Therapeutic simvastatin); Group IV (Therapeutic C. sativum); Group V (Prophylactic simvastatin); Group VI (Prophylactic C. sativum); Group VII (Simvastatin per se); Group VIII (C. sativum per se). Results obtained are significantly different from control group $(\# \mathrm{p}<0.05)$. Results obtained are significantly different from HF group ("p $<0.05)$. 
in the $\mathrm{ET}_{\mathrm{A}}$ and $\mathrm{ET}_{\mathrm{B}}$ receptor mRNA levels of C. sativum and simvastatin alone treated groups.

\section{Expression of $E T_{A}$ and $E T_{B}$ receptor protein levels}

Protein levels of $\mathrm{ET}_{\mathrm{A}}$ and $\mathrm{ET}_{\mathrm{B}}$ receptor was evaluated by western blotting. Expression level of $\mathrm{ET}_{\mathrm{A}}$ receptor protein was found to be significantly $(\mathrm{p}<0.05)$ upregulated in HF rats, when compared to the untreated control rats. However, in comparison with the HF rats, treatment with C. sati$v u m$ and simvastatin both therapeutically and prophylactically reduced their levels significantly $(\mathrm{p}<0.05)$ as observed in Figure 4A. Levels of $\mathrm{ET}_{\mathrm{B}}$ receptor protein was also found to be increased significantly $(\mathrm{p}<0.05)$, in comparison with the control group. Therapeutic treatment decreased the levels of $\mathrm{ET}_{\mathrm{B}}$ receptor protein significantly $(\mathrm{p}<0.05)$ in $C$. sativum and simvastatin groups accompanied by further downregulation of $\mathrm{ET}_{\mathrm{B}}$ receptor protein in prophylactic $C$. sativum and simvastatin groups significantly $(\mathrm{p}<0.05)$. The results are shown in Figure 4B. No significant change was assessed in the $\mathrm{ET}_{\mathrm{A}}$ and $\mathrm{ET}_{\mathrm{B}}$ receptor protein levels of $C$. sativum and simvastatin alone treated groups, when compared with the normal group.

\section{Histopathology}

Histological sections from left ventricle of control rats showed normal morphology. However, HF rats showed
A

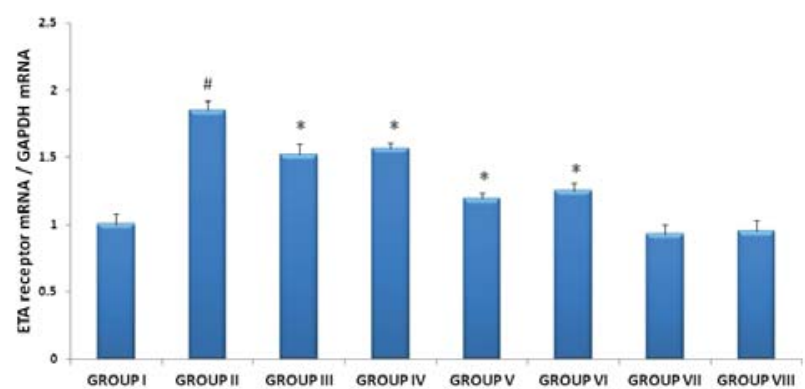

B

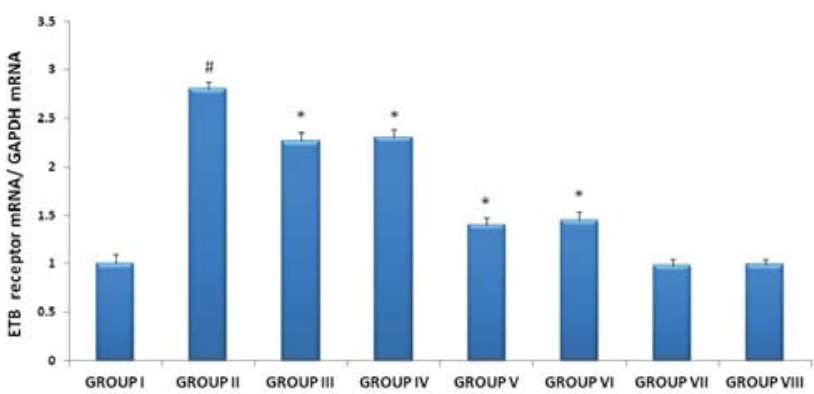

Figure 3: Real Time PCR results of $\mathrm{ET}_{\mathrm{A}}$ and $\mathrm{ET}_{\mathrm{B}}$ receptor mRNA in the LV (A) Relative mRNA levels of $\mathrm{ET}_{\mathrm{A}}$ receptor, (B) Relative mRNA levels of $\mathrm{ET}_{\mathrm{B}}$ receptor. Results represent mean \pm SEM of seven animals per group. Group I (Control); Group II (HF); Group III (Therapeutic simvastatin); Group IV (Therapeutic C. sativum); Group V (Prophylactic simvastatin); Group VI (Prophylactic C. sativum); Group VII (Simvastatin per se); Group VIII (C. sativum per se). Results obtained are significantly different from control group ( $\# \mathrm{p}<0.05)$. Results obtained are significantly different from HF group

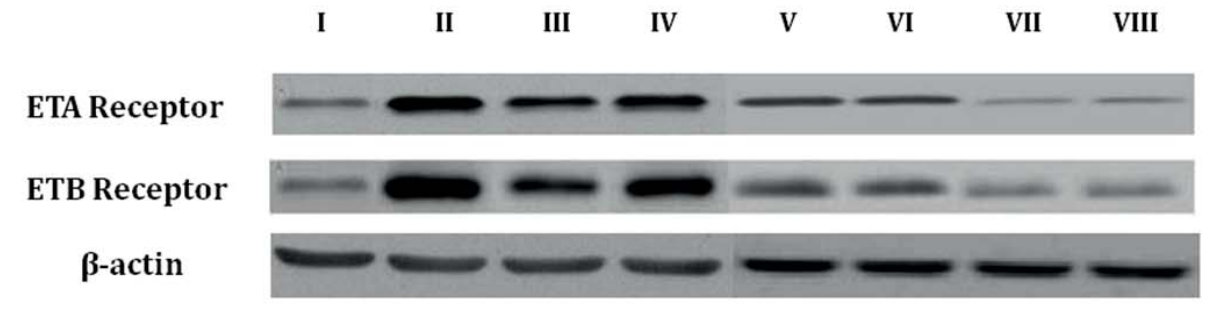

A

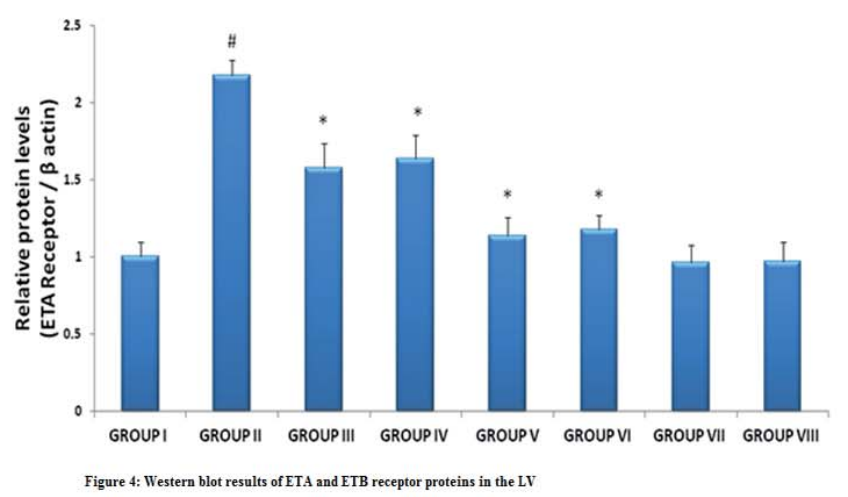

B

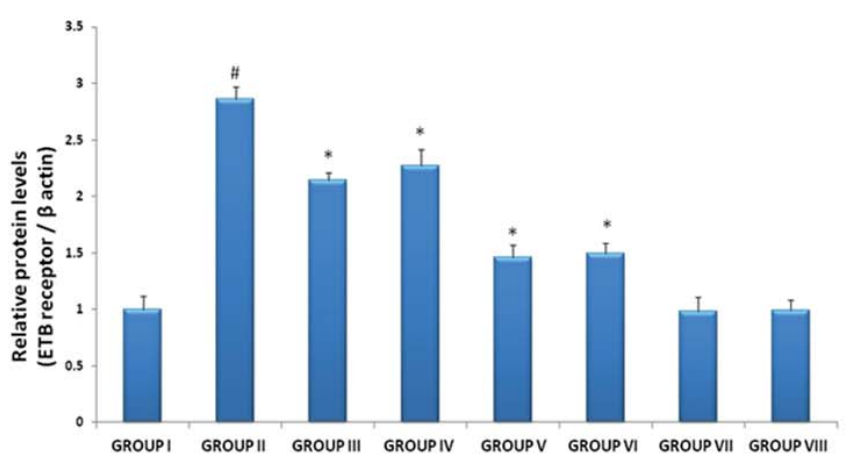

Figure 4: Western blot results of $\mathrm{ET}_{\mathrm{A}}$ and $\mathrm{ET}_{\mathrm{B}}$ receptor proteins in the LV. (A) $\mathrm{ET}_{\mathrm{A}}$ receptor protein expression level, (B) $\mathrm{ET}_{\mathrm{B}}$ receptor protein expression level. Results represent mean \pm SEM of seven animals per group. Group I (Control); Group II (HF); Group III (Therapeutic simvastatin); Group IV (Therapeutic C. sativum); Group V (Prophylactic simvastatin); Group VI (Prophylactic C. sativum); Group VII (Simvastatin per se); Group VIII (C. sativum per se). Results obtained are significantly different from control group $(\# \mathrm{p}<0.05)$. Results obtained are significantly different from HF group $($ ("p $<0.05)$. 

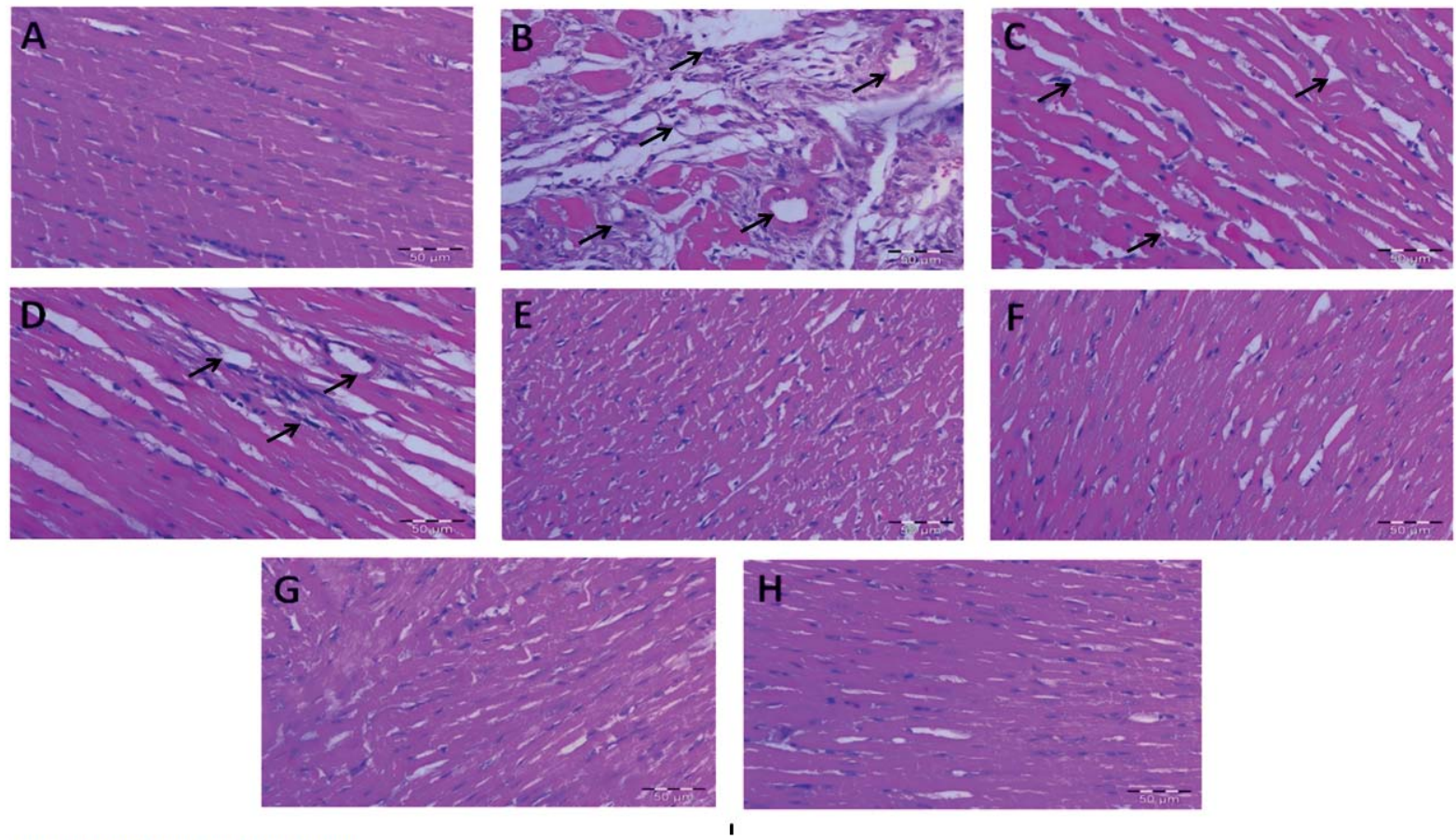

Figure 5: Histopathological changes in the myocardium

Figure 5: Histopathological changes in the myocardium (A) Control group showing normal architecture of cardiac myofibers (B) HF group showing alteration in myocardial structure with interstitial oedema, myocyte necrosis and inflammatory cell infiltration (C) Therapeutic simvastatin (D) Therapeutic C. sativum showing mild necrosis and inflammatory cell infiltration (E) Prophylactic simvastatin (F) Prophylactic C. sativum showing slight myocardial degeneration $(\mathrm{G})$ Simvastatin per se $(\mathrm{H})$ C. sativum per se. Specimens stained with hematoxylin and eosin.

distortion in the myocardial structure, myocyte necrosis with interstitial oedema and leucocyte infiltration. Therapeutic treatment with $C$. sativum and simvastatin showed partial improvement in myocardial morphology. However, prophylactic $C$. sativum and simvastatin treated groups showed marked improvement in the myocyte necrosis, interstitial oedema and leucocyte infiltration thereby restoring the normal myocardial morphology. No change in the myocardial architecture was observed from the histopathological sections of C. sativum and simvastatin alone treated groups (Figure 5).

\section{DISCUSSION}

The results of our present study clearly demonstrate the cardioprotective effect of Coriandrum sativum in isoproterenol induced HF rats. Isoproterenol (ISO), a synthetic catecholamine and a $\beta$-adrenergic receptor agonist induces myocardial necrosis leading to left ventricular hypertrophy. Mechanisms underlying ISO induced heart failure include oxidative stress due to excessive production of free radicals from oxidative metabolism of catecholamines, which result in both structural and functional myocardial injury $(28,29)$. Moreover, calcium overload and hypoxia followed by coronary hypotension and myocardial hyperactivity may be the cause for morphological alterations that results in myocardial damage (30). ISO induced heart failure serves as an excellent experimental model to evaluate the cardioprotective efficacy of various herbal and synthetic compounds.
Statin, a hypolipidemic drug is used in the treatment of chronic heart failure due to its ability to lower cholesterol levels, improve endothelial function, prevent thrombus formation and modulate inflammatory responses (31). Despite a number of beneficial properties, statins have been reported to cause detrimental effects like muscle toxicity, myopathy, rhabdomyolysis and liver damage (13). Hence, the development of alternate therapeutics which are safe and cost-effective is a good approach for the future. In this regard, herbal and natural products are being studied at the molecular and cellular level to understand their mechanism of action. In the present study, statins were used to compare its cardioprotective actions with the herbal drug C. sativum.

Pharmacological analysis of $C$. sativum seeds have revealed the presence of polyphenols (rutin, chlorogenic acid and caffeic acid derivatives), flavonoids (quercetin, isoquercetin, keampferol, rhamnetin and apigenin) and $\beta$-carotenoids $(32,33)$. The oil of Coriandrum sati$v u m$ seeds is rich in $\alpha$-pinene, $\beta$-pinene, camphor, citronellol, p-cymene, geraniol, limonene, linalool, myrcene, $\alpha$-phellandrene, terpinene, monoterpenoid glycosides and their derivatives (33). Many of these compounds are known to prevent oxidative stress by inhibiting free radical generation in the cellular system, when obtained through diet (33). Flavonoids are known for their anti-inflammatory, antitumor and antioxidant activities (34). Hence, these constituents in combination or independently may be responsible for the cardioprotective properties of $C$. sativum.

Hemodynamic changes have been reported in cardiovascular diseases $(35,36)$. Our present study showed 
significantly lower SBP, DBP, HR and MAP in HF rats as reported earlier (37). Therapeutic and prophylactic treatment with $C$. sativum and simvastatin, however attenuated the decline in SBP, DBP, HR and MAP, thus showing an improvement in altered hemodynamic profile.

Oxidative stress has been well implicated in the pathophysiology of cardiac remodeling and progression of heart failure (37). Increased production of reactive oxygen species damages the cell membrane lipids and causes lipid peroxidation. MDA is one of the final products of lipid peroxidation and a reliable marker for the assessment of oxidative stress (38). The enzymatic antioxidants are mainly involved in scavenging free radicals and reactive oxygen species. Previous studies have demonstrated that isoproterenol administration increases oxidative stress and depletes the level of cardiac GSH and antioxidant armory in the heart $(39,40)$. Our present study also suggested increased MDA formation and reduced GSH, GPx, GST, GR, catalase and SOD levels in HF rats. C. sativum treatment reduced MDA levels and improved the cardiac GSH content and antioxidant enzyme activities as reported previously (41) suggesting its free radical scavenging properties against cardiac oxidative stress in HF rats.

Lipids are known to play an important role in heart failure. Lipids provide structure and stability to cell membranes and changes in lipid profile may contribute to cell death resulting in myocardial ischemia. Altered lipid profile has been well established in cardiovascular diseases (42). Our present study demonstrated a significant increase in serum LDL, vLDL, total cholesterol, triglycerides and decrease in HDL levels in HF rats as reported previously (19). The mechanism of action of isoproterenol on fat cells is believed to be mediated by the cAMP cascade, where isoproterenol activates adenylate cyclase, thereby increasing the cAMP formation. Subsequently, cAMP promotes lipolytic activity by activating CAMP-dependent protein kinase that phosphorylates lipase resulting in the hydrolysis of stored triacylglycerol, which contributes to hyperlipidemia $(43,44)$. Therapeutic and prophylactic treatment with $C$. sativum however reduced the levels of total cholesterol, triglyceride, LDL, vLDL and increased HDL levels. Thus, C. sativum administration modulated the level of lipid and lipoproteins by decreasing lipid uptake and enhancing lipid breakdown suggesting the hypolipidemic property of C. sativum thus conferring cardioprotective effect. C. sativum has also known to inhibit the enzyme HMG CoA reductase which is the key enzyme in the pathway of cholesterol biosynthesis in liver (45). Simvastatin treatment in HF rats also showed a similar effect.

Atherogenic indices are powerful indicators of the risk of cardiovascular disease which is assessed by evaluating CRR, AC and AIP, the higher the value the higher the risk of developing heart disease. AIP has been reported to be a significant predictor of atherosclerosis (46). In our present study, HF rats showed a significant increase in CRR, AC and AIP. However, therapeutic treatment with $C$. sativum and simvastatin decreased CRR, AC and AIP which was further reduced by prophylactic treatment of C. sativum and simvastatin signifying their role in reducing the probability of cardiovascular pathogenesis.

Vascular endothelium has an important role in cardiovascular system regulation. Endothelin (ET-1) secreted from vascular endothelial cells is a potent vasoconstrictor, that has affinity for two types of receptors namely $\mathrm{ET}_{\mathrm{A}}$ and $\mathrm{ET}_{\mathrm{B}}$ receptor. Both these receptors co-exist on vascular smooth muscle cells (VSMC) that mediates vasoconstriction. In addition $\mathrm{ET}_{\mathrm{B}}$ receptors present on vascular endothelial cells (VEC) contributes to vasodilatation and ET-1 clearance (47). It has been suggested that in cardiovascular diseases, vasodilator $\mathrm{ET}_{\mathrm{B}}$ receptors may switch their phenotype to contractile $\mathrm{ET}_{\mathrm{B}}$ receptors $(48,49)$ and that the increased expression of $\mathrm{ET}_{B}$ receptors is directly correlated with the degree of ischemic heart disease (50). In the present study mRNA levels of $\mathrm{ET}_{\mathrm{A}}$ and $\mathrm{ET}_{\mathrm{B}}$ receptors was found to increase significantly in $\mathrm{HF}$ rats as compared to the control rats followed by increased expression of $\mathrm{ET}_{\mathrm{A}}$ and $\mathrm{ET}_{\mathrm{B}}$ receptor protein levels. Our data is consistent with the earlier studies (9). Therapeutic and prophylactic treatment with $C$. sativum and simvastatin reduced $\mathrm{ET}_{\mathrm{A}}$ and $\mathrm{ET}_{\mathrm{B}}$ receptor mRNA levels as compared with the HF treated rats. Their protein levels were also found to be significantly lower as compared with the HF rats.

C. sativum cardioprotective efficacy was further supported by histopathological studies. Histological findings revealed distorted myocardial architecture, cardiac myocyte hypertrophy, fibrosis and myocardial necrosis in isoproterenol induced rats. Therapeutic and prophylactic treatment with $C$. sativum and simvastatin alleviated isoproterenol induced myocardial changes and left ventricular hypertrophy. Hence, our results provide strong evidence indicating the cardioprotective efficacy of $C$. sativum against isoproterenol induced heart failure.

In conclusion, $C$. sativum may serve as an alternative herbal drug in protection from heart failure. The cardioprotective action of $C$. sativum may be due to its ability to improve the hemodynamic profile, alleviate oxidative stress, lower cholesterol levels, improve endothelial dysfunction and restore the cardiac morphology.

\section{ACKNOWLEDGMENTS}

Authors would like thank Central Council for Research in Unani Medicine (CCRUM), ministry of health, Govt of India for providing funds to carry out this research work.

\section{REFERENCES}

1. Bui AL, Horwich TB, Fonarow GC. Epidemiology and risk profile of heart failure. Nat. Rev. Cardiol. 2011; 8:30-41.

2. Mosterd A, Hoes AW. Clinical epidemiology of heart failure. Heart. 2007; 93:1137-1146.

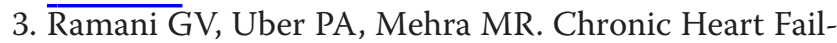
ure: Contemporary Diagnosis and Management. Mayo. Clin. Proc. 2010; 85:180-195. 
4. Moris D, Spartalis M, Spartalis E, Karachaliou GS, Karaolanis GI, Tsourouflis G, Tsilimigras DI, Tzatzaki $\mathrm{E}$, Theocharis $\mathrm{S}$. The role of reactive oxygen species in the pathophysiology of cardiovascular diseases and the clinical significance of myocardial redox. Ann Transl Med. 2017; 5(16): 326.

5. Choy PC, Siow YL, Mymin DOK. Lipids and atherosclerosis. Biochem. Cell. Biol. 2004; 82:212-24.

6. Daniels TF, Killinger KM, Michal JJ, Wright RW Jr, Jiang Z. Lipoproteins, cholesterol homeostasis and cardiac health. Int J Biol Sci. 2009; 5(5): 474-88.

7. Olatunji LA, Soladoye AO. Effect of increased magnesium intake on plasma cholesterol, triglyceride and oxidative stress in alloxan-diabetic rats. Afr. J. Med. Med. Sci. 2007; 36:155-61.

8. Xu CB, Sun Y, Edvinsson L. Cardiovascular risk factors regulate the expression of vascular endothelin receptors. Pharmacol. Ther. 2010; 127:148-55.

9. Kobayashi T, Miyauchi T, Sakai S, et al. Expression of endothelin-1, ETA and ETB receptors, and ECE and distribution of endothelin-1 in failing rat heart. Am. J. Physiol. 1999; 276:H1197-206.

10. Liao JK, Laufs U. Pleiotropic effects of statins. Annu. Rev. Pharmacol. Toxicol. 005; 245:89-118.

11. Kavalipati N, Shah J, Ramakrishan A, Vasnawala H. Pleiotropic effects of statins Indian J Endocrinol Metab. 2015; 19(5): 554-562.

12. Haehling SV. Statins for heart failure: still caught in no man's land? Clinical Science. 2009; 116:37-39.

13. Gotto AM. Statins, cardiovascular disease and drug safety. Am. J. Cardiol. 2006; 97:3-5.

14. Maghrani M, Zeggwagh N, Haloui M, Eddouks M. Acute diuretic effect of aqueous extract of Retamaraetam in normal rats. J. Ethnopharmacol. 2005; 99:31-35.

15. Lal AAS, Tkumar PBM. Pillai KS. Hypolipidemic effect of Coriandrum sativum L. intriton-induced hyperlipidemic rats. Indian J. Exp. Biol. 2004; 42:909-912.

16. Dhanapakiam P, Joseph JM, Ramaswamy VK. The cholesterol lowering property of coriander seeds (Coriandrum sativum): Mechanism of action. J. Environ. Biol. 2008; 29:53-56

17. Samojlik I, Lakic N, Mimica-Dukic N, Dakovic-Svajcer $\mathrm{K}$, Bozin B. Antioxidant and hepatoprotective potential of essential oils of coriander (Coriandrum sativum L.) and caraway (Carum carvi L.) (Apiaceae). J. Agric. Food Chem. 2010; 56:139- 147.

18. Patel DK, Desai SN, Gandhi HP, Devkar RV, Ramachandran AV. Food and Chemical Toxicology. Cardio protective effect of Coriandrum sativum L. on isoproterenol induced myocardial necrosis in rats. Food Chem. Toxicol. 2012; 50:3120-3125.

19. Parveen A, Babbar R, Agarwal S, Kotwani A, Fahim M. Terminalia arjuna enhances baroreflex sensitivity and myocardial function in isoproterenol-induced chronic heart failure rats. J. Cardiovasc. Pharmacol. Ther. 2012; 17:199-207.
20. Jollow DJ, Mitchell JR, Zampaglione N, Gillete JR. Bromobenzene induced liver necrosis: protective role of Glutathione and evidence for 3-4,bromobenzene oxide as the hepatotoxic intermediate. Pharmacology 1974; 11:151-159.

21. Mohandas M, Marshall JJ, Duggin GG, Horvath JS, Tiller D. Differential Distribution Of Glutathione And Glutathione Related Enzymes In Rabbit Kidney. Cancer Research 1984; 44:5086-5091.

22. Carlberg L, Mannervick B. Glutathione reductase level in rat brain. Journal of biological chemistry 1975; 250: 5575-5580.

23. Clairborne A. Catalase activity, CRC Press, Handbook of Methods for Oxygen Radical Research; R. Greenwald, 1985; Ed: 283-284.

24. Marklund S, Marklund G. Involvement of the superoxide anion radical in the autoxidation of pyrogallol and a convenient assay for superoxide dismutase. Eur J Biochem 1974; 47:469-474.

25. Wright JR, Colby HD, Miles PR. Cytosolic factors which affect microsomal lipid peroxidation in lung and liver. Arch. Biochem. Biophys. 1981; 206:296-304.

26. Ikewuchi JC, Ikewuchi CC. Alteration of plasma lipid profile and atherogenic indices of cholesterol loaded rats by Tridax procumbensm Linn: Implications for the management of obesity and cardiovascular diseases. Biokemistri. 2009; 21:95-9.

27. Pfaffl MW. A new mathematical model for relative quantification in real-time RT-PCR. Nucleic Acids Res. 2001; 29:2003-2007.

28. Khalil MI, Ahmmed I, Ahmed R, Tanvir EM, Afroz R, Paul S, Gan SH, Alam N. Amelioration of Isoproterenol-Induced Oxidative Damage in Rat Myocardium by Withania somnifera Leaf Extract. Biomed Res Int. 2015; 2015: 624159.

29. Sharma M, Kishore K, Gupta SK, Joshi S, Arya DS. Cardioprotective potential of ocimum sanctum in isoproterenol induced myocardial infarction in rats. Mol. Cell. Biochem. 2001; 225: 75-83.

30. Yeager JC, Iams SG. The hemodynamics of isoproterenol-induced cardiac failure in the rat. Circ. Shock. 1981; 8:151-63.

31. Dickinson MG, John H, Olshansky B, et al. Statin use was associated with reduced mortality in both ischemic and nonischemic cardiomyopathy and in patients with implantable defibrillators. Am. Heart. J. 2007; 153:573-578.

32. Melo EA, Bion FM, Filho JM, Guerra NB. In vivo antioxidant effect of aqueous and etheric coriander (Coriandrum sativum L.) extracts. Eur. J. Lipid Sci. Technol. 2003; 105:483-487.

33. Rajeshwari U, Andallu B. Medicinal benefits of coriander (Coriandrum Sativum L). Spatula DD. 2011; 1:51-58.

34. Kay CD, Hooper L, Kroon PA, Rimm EB, Cassidy A. Relative impact of flavonoid composition, dose and structure on vascular function: A systematic review of randomized controlled trials of flavonoid-rich food products. Mol. Nutr. Food Res. 2012; 256:1605-16. 
35. Yang L, Jia Z, Yang L, et al. Exercise Protects against Chronic $\beta$-Adrenergic Remodeling of the Heart by Activation of Endothelial Nitric Oxide Synthase. PLoS One. 2014; 9:e96892.

36. Simko F, Bednarova KR, Krajcirovicova K, et al. Melatonin reduces cardiac remodeling and improves survival in rats with isoproterenol-induced heart failure. J. Pineal Res. 2014; 57:177-84.

37. Tsutsui H, Kinugawa S, Matsushima S. Oxidative stress and heart failure. Am. J. Physiol. Heart Circ. Physiol. 2011; 301:H2181-90.

38. Gaweł S, Wardas M, Niedworok E, Wardas P. Malondialdehyde (MDA) as a lipid peroxidation marker. Wiad. Lek. 2004; 57:453-5.

39. Rajadurai M, Prince PSM. Preventive effect of naringin on lipids, lipoproteins and lipid metabolic enzymes in isoproterenol-induced myocardial infarction in Wistar rats. J. Biochem. Mol. Toxicol. 2006; 20:191-197.

40. $\bar{M}$ urugesan M, Revathi R, Manju V. Cardioprotective effect of fenugreek on isoproterenol induced myocardial infarction in rats. Indian J Pharmacol. 2011; 43(5):516-519.

41. Tang ELH, Rajarajeswaran J, Fung SY, Kanthimathi MS. Antioxidant activity of Coriandrum sativum and protection against DNA damage and cancer cell migration. BMC Complementary and Alternative Medicine. 2013; 13:347.

42. Giardano FJ. Oxygen, oxidative stress, hypoxia, and heart failure. J. Clin. Invest. 2005; 115:500-508.

43. Morimoto C, Kiyama A, Kameda K, Ninomiya H, Tsujita T, Okuda H. Mechanism of the stimulatory action of okadaic acid on lipolysis in rat fat cells. The Journal of Lipid Research. 2000; 41(2): 199-20.

44. Radhiga T, Rajamanickam C, Senthil S, Pugalendi KV. Effect of ursolic acid on cardiac marker enzymes, lipid profile and macroscopic enzyme mapping assay in isoproterenol-induced myocardial ischemic rats. Food Chem Toxicol. 2012; 50(11): 3971-7.

45. Dhanapakiam P, Joseph JM, Ramaswamy VK, Moorthi M, Kumar AS. The cholesterol lowering property of coriander seeds (Coriandrum sativum): mechanism of action. J Environ Biol. 2008; 29(1): 53-6.

46. Bafna A, Maheshwari RS, Ved RK, Sarkar PD, Batham AR. Study of atherogenic indices in nephrotic syndrome. Int. J. Biol. Med. Res. 2012; 3:2257-2260.

47. Ohkita M, Tawa M, Kitada K, Matsumura Y. Pathophysiological Roles of Endothelin Receptors in Cardiovascular Diseases. J. Pharmacol. Sci. 2012; 119:302 - 313.

48. Stenman E, Malmsjo M, Uddman E, Gido G, Wieloch T, Edvinsson L. Cerebral ischemia upregulates vascular endothelin ET(B) receptors in rat. Stroke. 2002; 33:2311-2316.

49. Zheng JP, Zhang Y, Edvinsson L, Hjalt T, Xu CB. NFkappaB signaling mediates vascular smooth muscle endothelin type B receptor expression in resistance arteries. Eur. J. Pharmacol. 2010; 637:148-154.

50. Dimitrijevic I, Edvinsson ML, Chen Q, Malmsjo M, Kimblad PO, Edvinsson L. Increased expression of vascular endothelin type B and angiotensin type 1 receptors in patients with ischemic heart disease. BMC Cardiovasc. Disord. 2009; 9:40. 